\title{
New and newly illustrated Gnomidolon Thomson (Coleoptera, Cerambycidae, Hexoplonini) from Bolivia
}

\author{
Robin O. S. Clarke
}

Hotel Flora and Fauna, Casilla 2097, Santa Cruz de la Sierra, Bolivia. hotelfandf@hotmail.com

\begin{abstract}
New and newly illustrated Gnomidolon Thomson (Coleoptera, Cerambycidae, Hexoplonini) from Bolivia. Three new species of Gnomidolon Thomson, 1864 (Coleoptera, Cerambycidae, Hexoplonini) from Bolivia are described and illustrated, and G. proseni Martins, 1962 is redefined. Photographs of G. proseni and four other Bolivian species of this genus are provided: G. bonsae Martins, 1967, G. nanum Martins, 1962, G. musivum (Erichson, 1847), and both pale and dark forms of G. wappesi Martins, 2006.
\end{abstract}

KEYWORDS. Cerambycinae; Neotropical; New species; Bolivia.

RESUMO. Novas espécies e ilustrações em Gnomidolon Thomson (Coleoptera, Cerambycidae, Hexoplonini) da Bolivia. Três espécies novas do Gnomidolon Thomson, 1864 (Coleoptera, Cerambycidae, Hexoplonini) da Bolívia são descritas e ilustradas, e G. proseni Martins, 1962 é redefinido. Fotografias do G. proseni e quatro outras espécies do gênero são fornecidas: G. bonsae Martins, 1967, G. nanum Martins, 1962 G. musivum (Erichson, 1847), e as duas formas, pálida e obscura, de G. wappesi Martins, 2006.

PALAVRAS-CHAVE. Cerambycinae; Neotropical; Novas espécies.

This paper presents descriptions and photographs of three new species of Gnomidolon Thomson, 1864. Two of these are very similar in appearance to G. proseni Martins, 1962 originally described from a single female specimen. G. proseni is redefined, now that further specimens (including males of this species) are available; and the first photographs of G. proseni, as well as the pale form of G. wappesi Martins, 2006 (that can easily be confused with $G$. proseni) are shown. A key to the four proseni-like species is provided. In addition, photographs of three other Bolivian species of this genus : G. bonsae Martins, 1967, G. nanum Martins, 1962, and G. musivum (Erichson, 1847) that have not been published before are presented.

All the species considered here conform to the definition of Gnomidolon as diagnosed by Martins (1967:159). However, since both $G$. parallelum new species and G. gemuseusi new species have rather long $(0,25 \mathrm{~mm})$ narrow spines on the inside of the mesofemur and even longer spines $(0,5 \mathrm{~mm})$ on the outside of the metafemur (as in some other members of the genus), it could be argued that they rightly belong to the genus Hexoplon Thomson, 1864. It seems better to place them in Gnomidolon rather than revive another debate as to the validity of maintaining the two genera as separate taxa. Species of Hexoplonini Martins, 2006 are normally sexually dimorphic, the sides of the prothorax of the male being punctuate, the female not so, but G. parallelum new species shows no such sexual difference.

Three of the proseni-like species (G. proseni, G. wappesi and $G$. friedi new species) are sympatric and have been taken together at light at the Hotel Flora and Fauna (a hilly locality, in disturbed tropical transition forest, $16 \mathrm{~km}$ from the foot of the eastern Cordillera Andina).

For this reason it was thought necessary to prepare standard descriptions of the proseni-like species and to detail their separation at length.

Measurements. Total length $=$ length from base of pronotum to anterior border of antennal tubercules + length of elytra. Elytron length is measured from its base to tip of apical spine.

The acronyms used in the text are as follows: Florida State Collection of Arthropods, Gainesville, Florida, USA (FSCA); Museo Noel Kempff Mercado, Universidad Autónoma Gabriel René Moreno, Santa Cruz de la Sierra, Bolivia (MNKM); Museu Nacional, Universidade Federal do Rio de Janeiro, Brasil (MNRJ); Museu de Zoologia, Universidade de São Paulo, São Paulo, Brasil (MZSP); Robin Clarke/Sonia Zamalloa private collection, Hotel Flora and Fauna, Buena Vista, Santa Cruz, Bolivia (RCSZ).

\section{Gnomidolon parallelum new species}

(Fig. 1)

Male. General colour dark chestnut to chestnut, basal half and extreme apices of elytra paler. Head and prothorax dark chestnut, pronotum paler at base. Scape, antennomere II and base of III chestnut, the rest uniform fulvous. Basal half of elytra cinnamon, this colour surrounding a rounded, testaceous patch laterally, the patch well defined, especially adjacent to suture and posteriorly where the cinnamon colour is suffused by a dusky oblique crescent; the whole separated from the dark apical band by an oblique, testaceous fascia 
slightly wider than width of scape. Apical half of elytra mostly occupied by a broad, dark chestnut fascia, its front edge extended obliquely forwards; apex of elytra testaceous, this pale band narrower than width of scape. Femora testaceous, tibia and protarsi dusky. Prosternum dark chestnut to chestnut, hind edge paler; meso- and metasterna rufous, much paler than prosternum and urosternites.

Superior lobes of eyes with 3 (2 laterally) rows of ommatidia. Scape cylindrical without lateral apical extension. Antennae reach apex of elytral spine at middle of antennomere VIII. Prothorax elongate, twice as long as wide, sides parallel, front and basal constrictions relatively weak, width of front and basal border equal. Apex of elytra conspicuously emarginate, apical spines straight, long $(0,3 \mathrm{~mm})$, equal to distance between inner base of spine and suture (fig. 12). Apices of mesofemora very unequal, lateral apex weakly acuminate, mesal apex (fig. 15 ) with long spine $(0,25 \mathrm{~mm})$; apices of metafemora also very unequal, laterally (fig. 18$)$ with very long spine $(0,5 \mathrm{~mm})$, mesally moderately acuminate.

Sexual dimorphism: apparently slight, the male pronotum lacking sexual puncturation.

Variation: the apex of elytra of one female slightly more emarginate than male, in the other obliquely truncate. In both females apical spines of elytra are slightly shorter $(0,25 \mathrm{~mm})$. One female with dusky oblique crescent black and widening to, almost, base of elytra, to occupy half the width of the cinnamon coloured area.

Measurements (mm) $10^{x} / 2$ o . Total length 8,6/8,2-9,1; length of pronotum 2,2/2,0-2,3; width of pronotum 1,1/1,0-1,2; length of elytra 5,5/5,3-5,9; humeral width 1,6/1,5-1,8.

Holotype: male, BOLIVIA, Santa Cruz, 400m, road to San Javier, $12 \mathrm{~km}$ ENE of Buena Vista, 16.XII.2005, R. Clarke/S. Zamalloa col., beaten from vine and stick tangles (MNKM). Paratypes with same data as holotype: 1 female (MZSP); 1 female 6.XII.2006 (RCSZ).

This wooded savanna (12 km ENE of Buena Vista), corresponding to Chiquitano Forest, has been severely disturbed by cattle ranching.

Discussion: G. parallelum is most easily separated from $G$. proseni by the characters used in the key. The pronotum, with its elongate, parallel sided form and elytra with deeply emarginate, or obliquely truncate apex, and long apical spine will, also, separate this species from $G$. proseni and other proseni-like species.

\section{Gnomidolon friedi new species}

(Fig. 2)

Female: General colour dark to pale chestnut, basal half and apices of elytra paler. Head almost black, prothorax dark chestnut. Scape dark chestnut, pedicel and first antennomere testaceous, paler than scape, more or less uniform in colour with rest of antenna. Basal half of elytra cinnamon, this colour surrounding an ill defined, testaceous, transverse patch laterally, behind which the cinnamon suffused by a dusky transverse mark; the whole separated from the dark apical band by a transverse, testaceous fascia distinctly wider than width of scape. Apical half of elytra mostly occupied by a broad, dark chestnut fascia, the front edge adjacent to the suture extended anteriorly; apex of elytra testaceous, this pale band distinctly narrower than width of scape. Legs testaceous, metafemora slightly dusky. Meso- and metasterna rufous, paler than prosternum and urosternites.

Superior lobes of eyes with 3 (2 laterally) rows of ommatidia. Sides of prothorax slightly excavate, base about as wide as front; sides of pronotum impunctate. Apex of elytra truncate, apical spines long $(0,3 \mathrm{~mm})$, equal to distance between inner base of spine and suture (fig. 11).

Mesal and lateral apices of mesofemur unequal, mesally acuminate (fig. 14), shorter laterally; apices of metafemur markedly unequal, mesally acuminate, laterally (fig. 17) with distinct long spine $(0,25 \mathrm{~mm})$.

Sexual dimorphism:, sides of male pronotum, from front to hind edge, with a line of fine, disperse punctures separated by twice their own diameter.

Constant characters: Scape cylindrical without lateral apical extension; antennomeres II and III always paler than scape; Meso- and metasterna rufous, always paler than prosternum and urosternites.

Variation: pronotum often paler at base and sometimes on disc; the dusky transverse mark suffusing the cinnamon area of the elytra may be absent; front edge of apical dark fascia sometimes straight; sides of pronotum sometimes parallel; lateral spine of metafemur may be shorter or longer $(0,2-0,3 \mathrm{~mm})$.

Measurements (mm) 60 $60^{x} / 12$ : Total length 7,3-8,6/7,4-9,0; length of pronotum 1,6-2,1/1,9-2,2; width of pronotum 0,9-1,2/ $1,1-1,3$; length of elytra $4,0-5,5 / 4,8-5,8$; humeral width $1,3-1,7$ / $1,4-1,8$.

Holotype female, BOLIVIA, Santa Cruz, 17²9'96"S/63 39'13"W, 420m, Hotel Flora \& Fauna, 5 km SSE Buena Vista, 1.XI.2005, R. Clarke/ S. Zamalloa col., at white light (MNKM). Paratypes with same data as holotype unless otherwise stated: 1 male, 14-16.X.2000 and 1 female, 1720.X.2000, R. Morris col., 1 female, 3-14.XI.2003 N. Woodley col. (MNKM); 1 female 10-15.XI.2002, 1 male 20-30.X.2003 (FSCA); 1 male 15.X.2004, 1 female 26.X.2004 (MNRJ); 1 male 29-30.X.2003, 2 females 4.XI.2004; 1 male 19.XI.2004 (MZSP); 2 males: 19.XI.2004, 28.10.2005, 3 females: 1.XI.2004, 23.XII.2004, 1.I.2005, 1 female 8.XI.2005 on flowers of "Piton Amarillo" tree (Talisia hexaphylla Vahl., Fam. SAPINDACEAE) (RCSZ).

This species is named after my cousin, Rony Fried, in recognition of his generous support of my entomological studies.

Discussion: The separation of this species from G. proseni is amply discussed under the latter's redescription. Its separation 

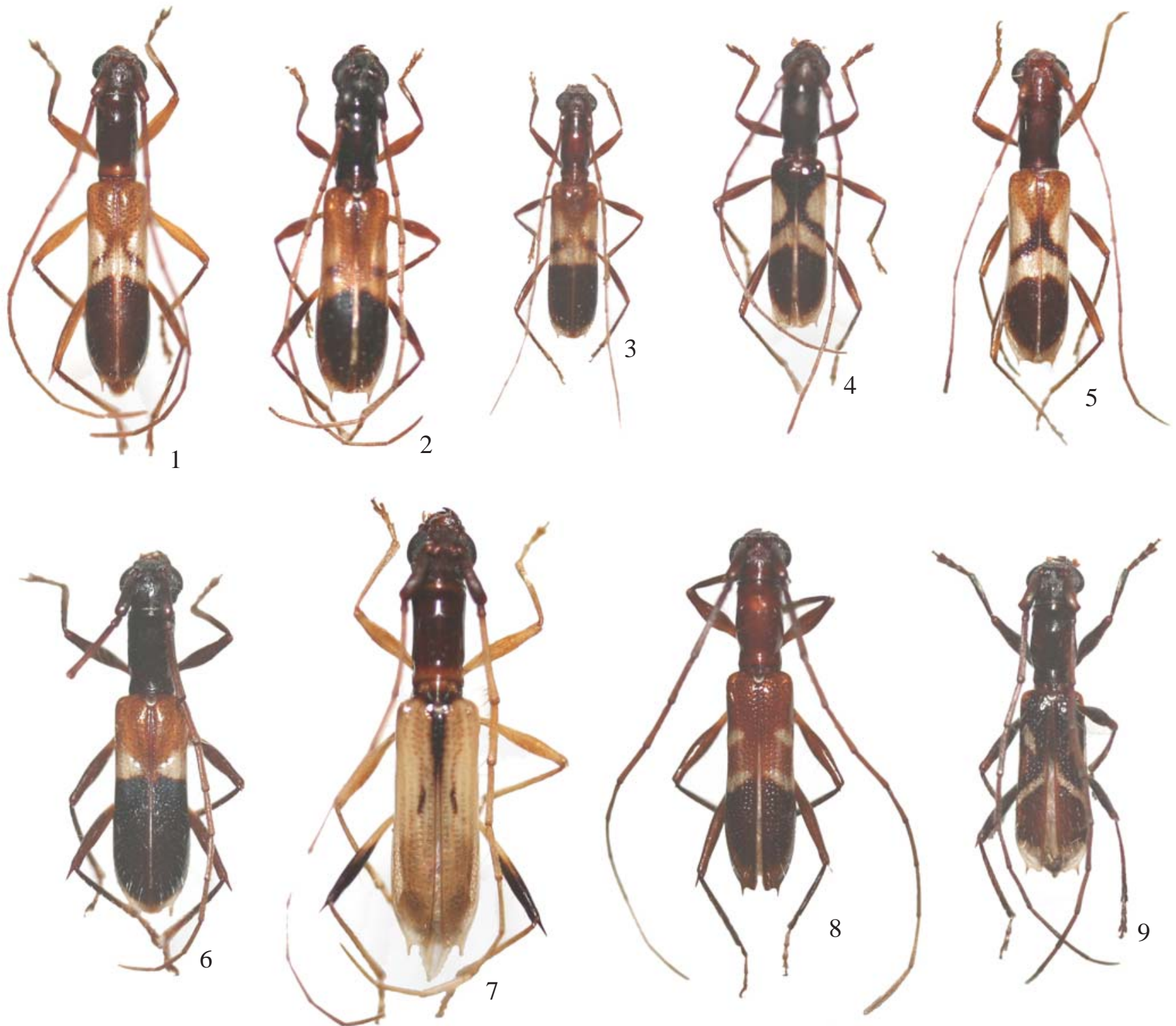

Figs. 1-9. 1, Gnomidolon parallelum new species, male holotype; 2, G. friedi new species, female holotype; 3, Gnomidolon proseni Martins, female; 4-5, Gnomidolon wappesi Martins, 4, dark form, male, 5, pale form, female; 6, G. gemuseusi new species, female holotype; 7, Gnomidolon bonsae Martins, male; 8, Gnomidolon nanum Martins, male; 9, Gnomidolon musivum (Erichson) dark form, male.

from G. parallelum is referred to under the description of this species. G. friedi is most easily separated from pale forms of $G$. wappesi by the characters used in the key.

\section{Gnomidolon proseni Martins, 1962}

(Fig. 3)

Gnomidolon proseni Martins 1962: 270, fig. 3; Martins 1967: 288 ; Martins 1971: 133; Martins 2006: 281; Monné 2005b: 313 (cat.).

Redescription: General colour dark to pale chestnut, basal half and apices of elytra paler. Head and prothorax unicolourous dark chestnut, less often pale chestnut. Scape, antennomere II and basal half of III dark chestnut, becoming increasingly paler toVI, VII-XI fulvous. Basal half of elytra cinnamon, this colour surrounding a moderately well defined, elongate, testaceous patch laterally, behind which the cinnamon colour may or may not be suffused by a dusky oblique mark; the whole separated from the dark apical band by a transverse, testaceous fascia about as wide as width of scape. Apical half of elytra mostly occupied by a broad, dark chestnut fascia, the front edge of which is usually straight or slightly excised at centre; apex of elytra testaceous, this pale band as wide as width of scape. Legs chestnut, tibia and tarsi paler, or sometimes uniform pale chestnut. Meso- and metasterna rufous, much paler than prosternum and urosternites.

Superior lobes of eyes with 2 rows of ommatidia. Scape cylindrical without lateral apical extension. Sides of prothorax subparallel, widest at apical $1 / 4$, sides distinctly narrowing to base. Apex of elytra truncate to moderately excavate, apical 
spines curved and usually not longer than $0,15 \mathrm{~mm}$ (except in the largest individuals), distinctly shorter than distance between inner base of spine and suture (fig. 10). Mesal and lateral apices of meso- and metafemora (figs. 13,16) lacking spines, slightly acuminate and subequal.

Sexual dimorphism: male pronotum distinctly punctured laterally, punctures relatively coarse and dense, separated by their own diameter.

Measurements (mm) 4 $0^{x} / 4$ \% : total length 5,3-6,9/6,7-7,6; length of pronotum $1,3-1,9 / 1,6-1,8$; width of pronotum $0,9-1,1 /$ 1,0-1,1; length of elytra 3,4-4,5/4,3-5,0; humeral width 1,1-1,4/ $1,3-1,4$.

Specimens examined (all with same data): BOLIVIA, Santa Cruz, 17²9'96"S/63³9'13"W, 420m, Hotel Flora \& Fauna, 4-6 km SSE Buena Vista, 1 male 10-15. XI. 2003, 1 female 30.XI.2004, 1 male 2230.XI.2003 R. Clarke col. (MNKM); 1 female 2.XI.2004, 1 male 9.XI.2004 (MZSP); 1 male, 1 female 18.X.2004, 1male, 1 female 30.X.2004 (RCSZ).

Discussion: As Martins (1971: 133, and Cerambycidae SulAmericanos Hexoplonini, 2006: 180) has pointed out Gnomidolon proseni, was described from a single female from Buena Vista, Bolivia, and one of two males from Mato Grosso (each a separate species) could correspond to the male of $G$. proseni. But, as he goes on to say, whichever male corresponds to G. proseni, this species would present difficulties for the classification of this genus because the males correspond to Group I species (with an external spine on the metafemur) whilst the female type specimen clearly corresponds to Group II species (metafemur lacking a true spine). Now that male specimens of G. proseni (collected at Buena Vista, the type locality) are available, which show no morphological difference to the female holotype (except for normal sexual differences), and no significant differences in colour distribution, it is clear that the Mato Grosso specimens do not belong to this species.

The species most often confused with G. proseni is G. friedi because they are sympatric and share a very similar elytral pattern. It is worth recalling that some G. proseni and some $G$. friedi lack the dusky mark just behind the pale lateral patch but, when present, the dusky mark in G. proseni is oblique and in G. friedi transverse.

With respect to the broad dark fascia occupying the apical half of the elytra, its front edge is usually straight in G. proseni (Fig. 3) and perpendicular to the suture, whereas in G. friedi (Fig. 2) its front edge is usually projected slightly forwards and, thereby, lies somewhat obliquely to the suture.

Other useful characters to separate these two species not mentioned in the key are: 1. prothorax of G. proseni widest just behind front, sides subparallel to basal constriction, hind margin noticeably narrower than front margin; in G. friedi sides to basal constriction parallel sided (although feebly excavate in some exx.) and basal margin not noticeably narrower than front margin; 2. colour of head and pronotum in G. proseni is dark chestnut, uniform in colour with scape; in G. friedi head and pronotum are blacker, slightly contrasting with scape which is dark chestnut; 3 . the extent of the rufous colour of the basal half of the elytra is less extensive and better defined in G. proseni (wineglass shaped) than it is in G. friedi (goblet shaped).

Separation of G. proseni from G. parallelum and G. wappesi can be found under the descriptions of these species.

Gnomidolon wappesi Martins, 2006

(Figs. 4-5)

Gnomidolon wappesi Martins, 2006: 178; Monné, M. A. \& F. T. Hovore 2006: 86.

G. wappesi, in its pale form, is the fourth proseni-like species from the Hotel Flora and Fauna, near Buena Vista, Bolivia. The darker forms are unlikely to be confused with proseni but pale forms look very similar to G. parallelum whilst, structurally, closest to G. friedi. For these reasons a description of the pale form is set out below.

Description of pale form: General colour pale chestnut, basal half and apices of elytra paler. Head, antennae and legs uniform pale rufous, prothorax duskier. Basal half of elytra cinnamon, this colour surrounding an oval testaceous patch laterally, the patch moderately well defined, especially adjacent to suture and posteriorly where the cinnamon is suffused by a dusky, oblique crescent; the whole separated from the dark apical band by an oblique, testaceous fascia distinctly wider than width of scape. Apical half of elytra mostly occupied by a broad, chestnut fascia, its front edge extended obliquely forwards; apex of elytra testaceous, this pale band slightly wider than width of scape. Underside pale rufous, sternites IIV suffused dusky.

Description of pale and dark forms: superior lobes of eyes with 3-4 (2-3 laterally) rows of ommatidia. Sides of prothorax converging towards base, widest near front margin. Apex of elytra truncate to moderately excavate, apical spines short $(0,1-0,2 \mathrm{~mm})$, shorter than distance between inner base of spine and suture. Mesal and lateral apices of mesofemur subequal, moderately acuminate; apices of metafemur unequal, mesally acuminate, laterally terminating in a moderately short spine $(0.15 \mathrm{~mm})$.

Sexual dimorphism: male pronotum punctured laterally, the punctures relatively large and dense, separated by 1-2 times their own diameter.

Measurements (mm) $3 \sigma^{x} / 2$ \%: Total length 6,1-7,2/7,3-8,2; length of pronotum 1,5-1,9/1,8-2,0; width of pronotum 0,9-1,1/ $1,0-1,2$; length of elytra $3,9-4,6 / 4,8-5,3$; humeral width $1,2-1,5 /$ $1,5-1,7$. 


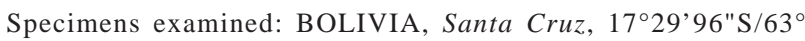
39'13"W, 420m, Hotel Flora \& Fauna, 4-6 km SSE Buena Vista, R. Clarke col., 1 male, 1 female 16.X.2005 (MNKM); 30. IX. 2004, 1 male 5. X. 2004, 1 male 7.X.2004, 1 female 9. X. 2005, R. Clarke/S. Zamalloa col. (RCSZ).

Discussion: Pale forms of G. wappesi are most likely to be confused with G. proseni (because they are sympatric, share similar colour patterns, conical pronota, and relatively short elytral spines) but the presence of a lateral metafemoral spine in G. wappesi will always separate this species from G. proseni. Separation of $G$. wappesi from G. parallelum is referred to under the description of this species; and from $G$. friedi by the characters used in the key.

Key to Gnomidolon proseni-like species.

1. Metafemora without apical spines, at most apices slightly acuminate (Fig. 16). Superior lobe of eye with rows of 2 ommatidia and not narrowed laterally. Apex of elytron with short slightly curved spine (Fig. 10), shorter than distance between inner base of spine and suture; legs uniform chestnut, tibia and tarsi paler or uniform pale chestnut, mesofemora without spines (Fig. 13). Fig. 3 .. G. proseni Martins, 1962

External apex of metafemora distinctly spined (Figs. 17, 18). Superior lobe of eye with rows of $x 3-4$ ommatidia, usually narrowed laterally to 2 rows ...

2. Apex of mesofemora (Fig. 15) and elytra (Fig. 12) with long spines about as long as metatarsomere II. Metafemoral spine very long (Fig. 18), as long as metatarsomere I. Apex of elytra strongly excavate or obliquely truncate. Legs testaceous, tibia and protarsi dusky. Fig.1

G. parallelum new species

Mesofemora without spines, at most apices acuminate (Figs. 14). Metafemora (Fig. 17) and apex of elytra (Figs. 10,11 ) with spines about as long as, or shorter than, metatarsomere II. Apex of elytra truncate or moderately excavate. Legs more uniform in colour

3. Apex of elytra with straight spine (Fig. 11) about as long as distance between inner base of spine and suture. Legs pale uniform testaceous; metafemora sometimes dusky, apical spine (Fig. 17) about as long as metatarsomere II. Fig. 2 G. friedi new species

Apex of elytra with short, slightly curved spine (similar to G. proseni, Fig. 10) shorter than distance between inner base of spine and suture. Legs uniform pale rufous. Metafemoral spine (similar to G. friedi, Fig. 17) shorter than metatarsomere II. Figs. 4-5 .....

G. wappesi Martins, 2006

Gnomidolon gemuseusi new species (Fig. 6)

Female: Robust looking species, described from a single specimen. General colour black to dark chestnut, basal 3/8 and

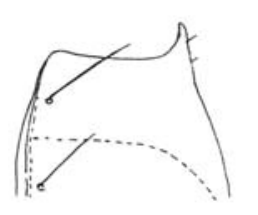

10

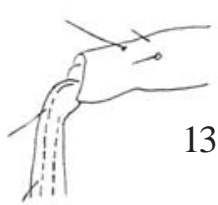

13

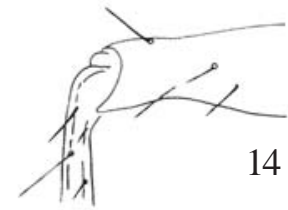

14
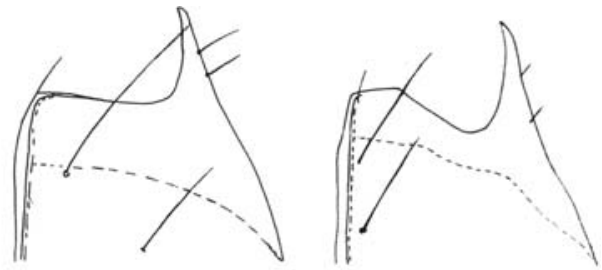

11

12
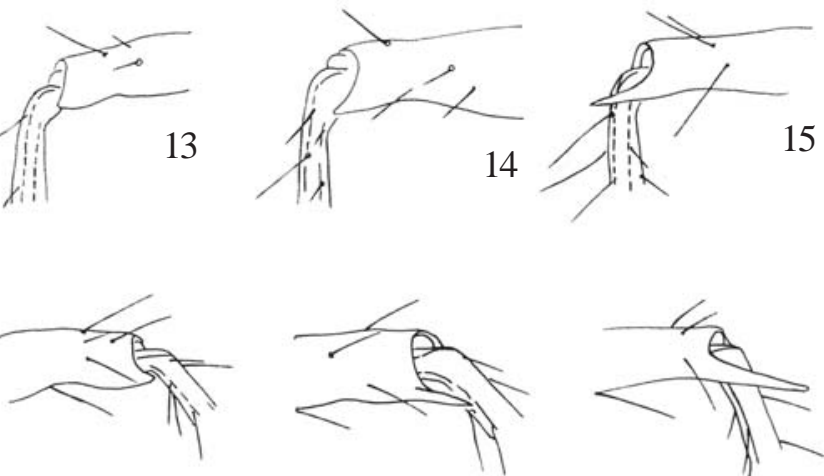

16

17

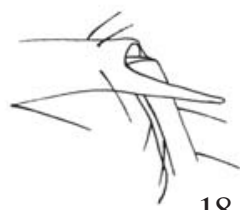

18

Figs. 10-18. 10-11, apex of elytra: 10, Type 1: G. proseni Martins; 11, Type 2: G. friedi new species; 12, Type 3: G. parallelum new species. 13-15, apex of mesofemur, dorso-mesal view: 13, Type 1: G. proseni Martins; 14, Type 2: G. friedi new species; 15, Type 3: G. parallelum new species. 16-18, apex of metafemur, dorso-lateral view: 16, Type 1: G. proseni Martins; 17, Type 2: G. friedi new species; 18, Type 3: G. parallelum new species.

extreme apices of elytra paler. Head and prothorax black, prothorax with only a slight chestnut hue. Scape and pedicel dark chestnut, antennomere III slightly paler, the rest uniform fulvous. Basal 3/8 of elytra cinnamon, posteriorly replaced by two, large, well defined, triangular, pure white marks (these marks slightly elevated above the surface of the elytra as in many Eburiini). Apical 5/8 of elytra occupied by a black band, the front edge of which lies perpendicular to the suture; extreme apex of elytra narrowly testaceous, this pale band narrower than width of scape. Legs chestnut, femora, apices of meso- and metatibiae, and tarsi paler. Meso- and metasterna rufous, much paler than prosternum and urosternites which are black.

Superior lobes of eyes with 3 (2 laterally) rows of ommatidia. Sides of pronotum almost parallel, front constriction absent, basal constrictions relatively weak, width of front and basal borders subequal. Apex of elytra deeply emarginate, apical spines long $(0,3 \mathrm{~mm})$, equal to distance between inner base of spine and suture. Apices of mesofemora very unequal, lateral apex moderately acuminate, mesal apex with long spine $(0,3$ $\mathrm{mm})$; apices of metafemora also very unequal, laterally with very long spine $(0,5 \mathrm{~mm})$, mesally with small tooth. Spine at apex of elytra long $(0,3 \mathrm{~mm})$, equal to distance between inner base of spine and suture. Apices of mesofemora very unequal, lateral apex weakly acuminate, mesal apex with long spine $(0,25$ $\mathrm{mm}$ ); apices of metafemora also very unequal, laterally with very long spine $(0,5 \mathrm{~mm})$, mesally moderately acuminate. 
Measurements (mm) 1 ; : Total length 9,2; length of pronotum 2,3; width of pronotum 1,3; length of elytra 5,9 ; humeral width 1,9 .

Holotype female, BOLIVIA, Santa Cruz, 17²9'96"S $/ 63^{\circ}$ 39'13"W, 420m, Hotel Flora \& Fauna, 5km SSE Buena Vista, 11.XII.2004, R. Clarke/S. Zamalloa col., at white light (MNKM).

This species is named after my brother, Ronald Victor Gemuseus, in recognition of his generous support of my entomological studies.

Discussion: G. gemuseusi is a very distinctive species unlikely to be confused with any other. The robust spines of the femora and the colour pattern of the elytra (with their triangular white marks and lack of a pale fascia separating the two halves of the elytra) separates this species from all those species in which the elytra are equally divided into pale and dark coloured halves.

The opportunity is taken to add further data and publish photographs in colour of three other species of Gnomidolon, also taken at light at the Hotel Flora and Fauna. These are as follows:

\section{Gnomidolon bonsae Martins, 1967}

(Fig. 7)

This species is endemic to Bolivia; originally described by Martins (1967: 268) from a single male specimen taken in the Department of Cochabamba (Rio Juntas). Martins (1971: 131) records a female for the Department of Beni. Recently, this readily identifiable species has been found to be relatively common in the Buena Vista area, in the Department of Santa Cruz. With these specimens it can be confirmed that females lack the sexual puncturation of the males, but otherwise conform to Martins' original description.

Measurements (mm) $10^{x} / 2 \%$ : Total length 8,7/8,8-10,2; length of pronotum 3,2/3,2-3,5; width of pronotum 1,2/1,1-1,4; length of elytra 5,5/5,6-6,7; humeral width 1,7/1,7-2,1.

\section{Gnomidolon nanum Martins, 1962}

(Fig. 8)

This species is also endemic to Bolivia; originally described by Martins (1962: 269) from a single, presumably, male specimen taken at Buena Vista (Department of Santa Cruz) by F. Prosen in 1949. In his Monograph of the Ibidionini, Martins (1967: 200-202), redescribed the species adding: "Partes laterais do protórax nos machos (x40) com alguns pontos evidentes" and confirmed the sex as male. Martins (2006: 155-156) account of the species was still based on the only specimen known at that time. Today, more specimens of $G$. nanum have been collected at lights at the Hotel Flora and Fauna, $5 \mathrm{~km} \mathrm{SE}$ of the type locality. With these specimens it is possible to verify that the anterior lateral surface of the pronotum in the male has a small group of indistinct, shallow, fine punctures, whereas in the female it is completely smooth, but otherwise shows little sexual dimorphism; and, from the three specimens available to the author, no difference in size.

Measurements (mm) $2 \sigma^{x} / 1$ i : Total length 7,6-9,7/9,2; length of pronotum 2,0-2-3/2,3; width of pronotum 1,1-1,3/1,2; length of elytra 4,8-6,2/5,8; humeral width 1,5-1,8/1,8.

\section{Gnomidolon musivum (Erichson, 1847)}

(Fig. 9)

This essentially Amazonian species is known to occur in northern South America, from E. Venezuela south to Mato Grosso, Brasil and northern Peru south to Santa Cruz, Bolivia.

In his Monograph of the Ibidionini, Martins (1969: 825826), provisionally placed Ibidion musivum Erichson, 1847 in the genus Compsibidion Thomson, 1864, with reservation as to its correct placement pending opportunity to examine the holotype. Martins (1971: 1429-1430) after examining the holotype was able to confirm the true position of this species as being in the genus Gnomidolon. At the same time he recognised Gnomidolon subeburneum (White, 1855) to be a junior synonym of G. musivum. Since only illustrations of the pale form have been published before the opportunity to present a photograph of the dark form has been taken.

Acknowledgements. A special thank you to Dr. Ubirajara Martins for reviewing a draft version of this manuscript and encouraging me to prepare it for publication. I am grateful to Dr. Michael Nee, Curator of the New York Botanical Gardens, for supplying the latin name for "Piton Amarillo". Thank you, also, to Julieta Ledezma for the loan of specimens under her care at the MNKM. Lastly, I would like to thank my wife, Sonia, for her continuous help with the field work.

\section{REFERENCES}

Martins, U. R. 1962. Ibidionini (Col., Cerambycinae) XV. Novas espécies, notas sinonímicas, redescrições. Papéis Avulsos de Zoologia 14: 267-310.

Martins, U. R. 1967. Monografia da tribo Ibidionini (Coleoptera, Cerambycidae) Parte I. Arquivos de Zoologia 16: 1-320.

Martins, U. R. 1969. Monografia da tribo Ibidionini (Coleoptera, Cerambycidae) Parte III. Arquivos de Zoologia 16: 631-877.

Martins, U. R. 1971. Monografia da tribo Ibidionini (Coleoptera, Cerambycidae) Parte VI. Arquivos de Zoologia 16: 1343-1508.

Martins, U. R. 1971. Notas sobre Cerambycinae (Col., Cerambycidae) VI. Subsídios ao conhecimento dos Ibidionini. Arquivos de Zoologia 21: 121-178.

Martins, U. R. (Organizador), 2006. Cerambycidae Sul-americanos (Coleoptera). São Paulo, Sociedade Brasileira de Entomologia. v. 8, p. I-II + 21-234.

Monné, M. A. \& F. T. Hovore. 2006. Checklist of the Cerambycidae, or longhorned wood-boring beetles, of the Western Hemisphere. Rancho Dominguez, BioQuip. 349 p. 